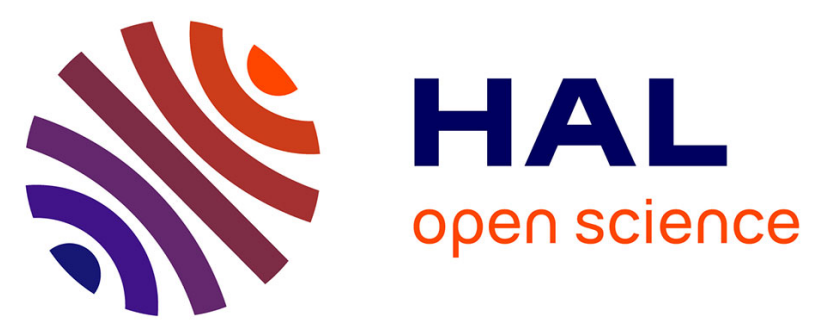

\title{
The Problematic Acquisition of Indigenous Languages: Practices and Contentions in Missionary Specialization in the Jesuit Province of Peru (1568-1640)
}

Aliocha Maldavsky

\section{- To cite this version:}

Aliocha Maldavsky. The Problematic Acquisition of Indigenous Languages: Practices and Contentions in Missionary Specialization in the Jesuit Province of Peru (1568-1640). O'Malley, John W.; Bailey, Gauvin Alexander; Harris, Steven J; Kennedy, T. Frank. The Jesuits II: Culture, Sciences, and the Arts (1540-1773), University Of Toronto Press, pp.602-615, 2006, 0-8020-3861-1. hal-01402508

\section{HAL Id: hal-01402508 \\ https://hal.parisnanterre.fr/hal-01402508}

Submitted on 9 Jan 2018

HAL is a multi-disciplinary open access archive for the deposit and dissemination of scientific research documents, whether they are published or not. The documents may come from teaching and research institutions in France or abroad, or from public or private research centers.
L'archive ouverte pluridisciplinaire HAL, est destinée au dépôt et à la diffusion de documents scientifiques de niveau recherche, publiés ou non, émanant des établissements d'enseignement et de recherche français ou étrangers, des laboratoires publics ou privés. 


\section{7 / The Problematic Acquisition of Indigenous \\ Languages: Practices and Contentions in \\ Missionary Specialization in the \\ Jesuit Province of Peru (1568-1640)}

\author{
ALIOCHA MALDAVSKY
}

Without indigenous languages, 'here theology would be speechless in preaching the gospel,' wrote a Jesuit about Peru in 1636. 'The Jesuits left behind many printed documents that attest to their linguistic endeavours in the Americas. The memory of authors such as Juan Ruiz de Montoya and Diego González Holguín lives on through these written fragments, which include catechisms and confession manuals as well as grammar and vocabulary books in indigenous languages, especially Quechua and Aymara. However, these eminent linguists represent only the visible tip of the iceberg. In the 1580 s, General Claudio Acquaviva requested that indigenous languages be taught throughout Brazil, Peru, and Mexico to Jesuits preparing for priesthood. My analysis focuses on the ways in which this widespread instruction about local languages was carried out in the Viceroyalty of Peru during the first sixty years of the Jesuit province's existence, on the evidence of documents that have been little studied and for the most part remain unpublished. The study highlights the reluctance and hesitation such instruction encountered, and its significance for missionary identity in the province. The debates among the members of the Peruvian province emphasize the difficult relationship that often existed between the missions and colonial society.

\section{Learning Indigenous Languages in Peru}

\section{The General Situation in Peru}

In 1568, when the Society of Jesus arrived in Peru, the Spanish policy was to encourage friars and priests to learn the indigenous languages, especially when they were responsible for the evangelization of Indians in their parishes, called doctrinas in Spanish America. Even if the Crown encouraged the 'Castilianization' of elites, it encouraged the use of local languages in catechesis and preaching, which was in accord with the dictates of the Council of Trent (1545-63). These dictates reinforced an existing trend. As early as 1215, Lateran Council IV had insisted on the importance of preaching in vernacular languages. Peruvian councils and synods reiterated this point when ordering priests to learn local languages. In Peru, the languages in question were Quechua and Aymara, those most spoken by the Andean people. As Robert Ricard wrote about the Nahuatl language in New Spain, these languages were used as 'auxiliary' languages in the evangelization of Peru. The first Quechua lessons were given in 1551 in the cathedral of Lima. Among the Dominicans who were in charge of this instruction, the most important was Domingo de Santo Tomás, the author of the first Quechua grammar. A chair of Quechua was founded at the University of San Marcos in Lima in 1579.

\section{Language and Local Recruitment in the Society of Jesus}

Jesuits could not avoid learning Indian languages, since their method of evangelization was based on teaching Christian Doctrine and administering sacraments, particularly confession. They maintained contact with Andean Indians first in the cities where they had their colleges, and then - especially - during the 'flying' missions they made periodically in teams of two into the Andean highlands and along the Peruvian coast. They also undertook remote missions, as far away as the borders of modern-day Chile and Paraguay. But unlike the other religious orders, the Jesuits of Peru refused at first to assume responsibility for doctrinas as ordinary priests. Nevertheless, in the 1570s, Viceroy Francisco de Toledo forced them to do so in Santiago del Cercado, on the outskirts of Lima, and in Juli, on the shores of Lake Titicaca. By the time of his arrival in Peru, the Society of Jesus had already been confronted with linguistic challenges in other places, such as Brazil and India. In order to ensure their linguistic efficiency, they adopted a strategy in Peru that focused on local recruitment. Local criollos (native Peruvians of European descent) or mestizos (Peruvians of mixed blood) who mastered indigenous languages could act as interpreters or share their knowledge with the Jesuits who came from Europe. This skill-sharing had been theorized as early as the 1550 s by Jesuit authorities in Rome. The locals would offer their knowledge, while the Europeans would form them in the Society's 'way of proceeding.' This approach aimed to adapt the Society of Jesus to local conditions and ensure its unity in spite of challenging geographical distances.

In 1.568, the provincial superior Diego de Bracamonte justified the recruitment of "colonial-born young people" on the ground that all of them knew the

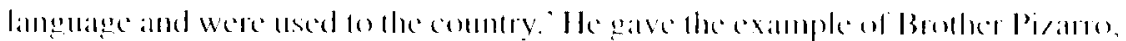


a scholar who taught catechism in Quechua in Lima. The documents have not revealed whether this descendant of a conquistador was a mestizo or a Spaniard. ${ }^{2}$ Later, in the catalogue of 1576, Father Juan de la Plaza abundantly praised the linguistic skills of the American-born Jesuits, as though doing so would help to justify their presence in the Society amid a general atmosphere of racial discrimination. Among them there were five mestizos given the title of 'lengua' (tongue), without any further indication of their level of linguistic knowledge. This title referred to the individual's ability to communicate in Quechua or Aymara. The mestizo himself was the 'tongue,' because he filled the role of spokesman for the Jesuits. There is no doubt that the admission of Blas Valera (in November 1568) and Bartolomé de Santiago (in 1574) gave a first impulse to the policy of indigenous language-learning in the Society of Jesus in Peru. ${ }^{3}$ These two mestizos went on to translate the catechism of the Third Council of Lima (1583), under the supervision of José de Acosta.

\section{The Circle of Language: From Learning to Teaching}

Language chairs were quickly established in the Jesuit colleges of the viceroyalty to deal with instruction in linguistic theory. Approved by the civil and religious authorities, this teaching applied to members of the order and the local clergy alike. The teaching of Quechua began in Lima at least as early as 1575 . Later on, at the end of the sixteenth century, it reached Potosí and La Plata (Sucre). Very quickly, owing to their mastery of the local languages, which was acknowledged and demonstrated beyond a doubt by their books. the Jesuits took on the role of linguistic experts for the viceregal authorities. In 1599 the viceroy called upon some Jesuits in Cuzco to test the knowledge of men who wished to become priests, in Quechua, Ayamara, and Puquina, the last being another language of the highlands. Even if this role was reserved for a minority of Jesuits, their reputation was based on a language-learning policy derived from frequent contact with the indigenous population. This interaction took place in the doctrinas, which were the true language schools for the Jesuits in Peru.

The provincial congregation of 1576 clearly differentiated between the theoretical and the practical conditions of language learning: 'Both general languages, Quechua and Aymara, of such an extended kingdom, must be industriously learned by Ours, because they are really necessary for the Lord's benefit. At least a smattering of them, firmly established by learning the art, will be taught in the colleges. But then Ours must gain the perfect linguistic talent in the Indian doctrinas through practising and training. The Indian doctrinas are the easiest and the most convenient place for that, and there is no other shortest and most suitable way to the ministry of preaching.' ${ }^{4}$ The Juli doctrina very soon became a centre for learning Aymara. At the beginning of the seventeenth century, the Jesuits of Peru considered diversifying their learning policy by taking on another doctrina to found a Quechua school.

The experience here was very similar to the experiences the Jesuits had in Brazil, with the aldeias, and in New Spain, where they had two parishes - one outside Mexico City called Tepozotlán, where Indians spoke Nahuatl, and the other in Pátzcuaro (Michoacán), where Indians spoke the Tarascan language. The learning methods were actually more intensive and practical in the doctrinas than in the colleges, where they tended to be theoretical. In Juli the method focused mostly on preaching, as the provincial wrote in 1579: 'They practise a lot, and every day they meet for one or two hours in order to talk and do numerous composition and translation exercises. And it is our experience that, by this method, in four or five months Ours can learn the Indian language sufficiently to hear confessions and teach catechism. Then, after a year, they are able to preach. This way, five of Ours now preach with great facility and eloquence. And we pay great attention to this, because experience shows that this is the way to convert Indians. 5 Some personal letters also refer to the stay in the doctrina to learn Indian languages. In 1625, Buonaventura Beati, a brother from Italy, wrote from La Paz after he had gained proficiency:

It has already been a year since I began learning the Aymara language, to help the gentiles; praise be to God, I can hear confessions and preach in the Indian language, even if it is not easy because I have just started doing it. With God's help, it will be easier in a while, and if not, we can suffer everything for such a good God. Thank God I am healthy, healthier than in Italy. In a few days I will be sent on mission for the first time. I am living in the college of Chuquiabo [La Paz] for the time being, and I spent ten months in the residence of Juli in order to learn the language after I left Lima, where I took my third year after the end of studies. I cannot write any longer because my time is taken up by continual confessions. ${ }^{6}$

We cannot say for sure whether the Jesuits of Peru all went to Juli to learn Aymara, because there were never more than ten residents in that doctrina at any one time. The time required to become a preacher (at least one year) left little room for rotation. The more gifted were certainly sent to Juli, and most of the others had a smattering of Quechua, which they acquired in the colleges. Nevertheless, it is difficult to determine the number of Jesuits who were proficient in an indigenous language, since such information was not systematically recorded in the catalogues. Why did the Peruvian calalogues kave out this information, when banguage skill wals a crucial component of the Ratrilian

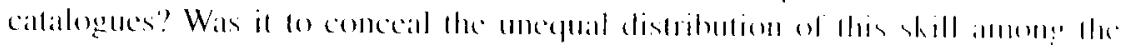


members of the province? Because learning was long and arduous, the question of indigenous language facility leads to the question of specialization in missionary activity. Language was an instrument of evangelization. Accordingly, the degree of linguistic facility among the Jesuits in a given province or college reflected the importance of missionary activity in that province or college. During the seventeenth century a debate on language-learning developed in the Peruvian province, and documents demonstrate that it was possible for students to avoid learning the indigenous languages in any depth. This evidence clearly demonstrates that missionary goals were not accepted unanimously by the members of the Society of Jesus in Peru.

\section{Language and Missionary Specialization: Questioning the Mission}

The Debate over Acquaviva's Order: The Missionary and the Professor

In the late 1570 s, Jesuit authorities in Rome enjoined the members of overseas provinces to learn local languages systematically as an instrument of evangelization. Francisco Borja wrote to the province of New Spain in 1579, 'It would be a good thing if nobody were ordained before he had learned one of the general languages spoken in those kingdoms. ${ }^{7}$ In 1583, Claudio Acquaviva reiterated this order in his instructions to the Peruvian province. ${ }^{8}$ In 1594 , thanks to the Fifth General Congregation, knowledge of indigenous languages became compulsory for Jesuits living in the Indies. The provincial congregations in Peru frequently repeated this decree. It was also one of the requirements incorporated by José de Acosta in his De procuranda Indorum salute, which he was preparing in the $1570 \mathrm{~s}$ and $1580 \mathrm{~s}$. But elements of a polemic concerning indigenous language-learning are to be found in letters written at the beginning of the seventeenth century. At that time, Jesuits in Peru began questioning the validity of having all members in the province learn Quechua and Aymara.

In March 1601, Nicolas Durán, the superior of Juli and the founder of the province of Paraguay some years later, complained about superiors who failed to learn indigenous languages. He wrote, 'In houses where the superior does not know the language, the Indian ministries are so lethargic that they are nothing like the colleges of the Society." Some Jesuits "fear inferior occupations especially when they are in touch with Indians,' and refuse to be assigned to them by stating their dislike. ${ }^{10}$ Such behaviour ran counter to the obedience that was supposed to prevail throughout the Society of Jesus. In Nicolas Durán's opinion, the consequence was that "peace cannot prevail in this province without equal division of labour, because it frequently comes to pass that those who know the language work day and night, and those who do not know it, since there is very little work to do among the Spanish people, spend their time studying or talking with the lay people." ${ }^{11}$ Their duty, however, was to help others; furthermore, "the language is very easy to learn, and whoever wants to learn it can do so and preach and hear confessions reasonably well after six months. ${ }^{12}$ He felt anxious about the indigenous languages and the future of the apostolate to the Indians if no solution was to be found.

Nine months later, the rector of Cuzco, Diego Alvarez de Paz, expressed the very opposite opinion. According to him, even if 70 per cent of the Jesuits had to learn indigenous languages - since Indians made up the majority of the population - this requirement did not apply to the remaining 30 per cent. ${ }^{13}$ He wanted tasks to be divided among those who evangelized the Indians, those who governed, and those who undertook spiritual activities. Preference for Indian ministry should govern the choice of the Jesuits who became missionaries. Applying a general rule to all the members of the province would simply not work. In Paz's opinion, there should be a hierarchy of Jesuits' 'occupations' within the Society. He wrote further that 'ministry to the Indians requires little study, because it is not necessary to tell them about subtle concepts or preach Holy Scripture. On the contrary, one does better and more appropriately to employ a simpler, everyday language for them. By contrast, ministry to the Spanish requires study. The preacher has to be heard and the confessor cannot make mistakes. 14

This was not the only intellectual rift between the missionaries and the rest of the Peruvian province. Diego Alvarez de Paz believed that there was a difference between them from a spiritual and disciplinary point of view as well. He wrote, 'Ours who go on too many missions acquire an abstracted and unquiet spirit, which is so far from devotion, and so little concerned with religious discipline and prayer, that when they come back nobody recognizes them and can straighten them out again.' ${ }^{15}$ He thought that ministry to the Indians was a waste of personnel because, 'for the sake of the Indians' care, the province is deprived of people who could serve it in much more important matters, and they are sent to very distant missions, concerning the benefit to which I can say nothing because I have never participated in them. But I have heard very diverse opinions among Ours: some say the benefit is very great, and others say the contrary, and thus there is little we can do.' 16

These doubts about remote missions applied to those being founded in the provinces of Tucuman (present-day Argentina) and Chile. Diego Alvare $z$ de Paz had fewer doubts about the 'flying' missions, for which 'a large number of people is not necessary, because the fruits of the missions are not as greal as they imagine over there / that is, in Romel. That is heyond doubl becaluse of the very

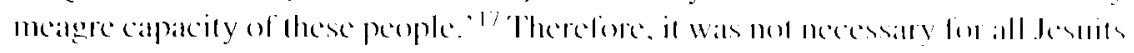


to learn the indigenous languages. The rector of Cuzco could not understand why the fathers who devoted themselves to the missions wanted to apply the language rules so passionately. He wrote, 'They are so fooled by this order and so blind that they are convinced there is nothing more pleasing to God than to hear the confessions of four little Indians. ${ }^{18}$ In his opinion, these laws brought about a division between the missionaries and the rest of the Society. The first 'have a privileged air about them, and think they are the only ones who belong to the Society, and that the others do not belong to it. ${ }^{19}$ This debate reveals how knowledge of indigenous languages clearly determined missionaries' specialization. The Jesuits' individual destinies were directly influenced by the policy of learning local languages for the purpose of evangelization. It was owing to this link that we can observe the same reluctance among their students.

\section{Contempt for the Missions}

Examples confirm a lack of vocation for mission work among some of the Jesuits in Peru. In 1617, General Muzio Vitelleschi reacted concerning 'Father Sebastián Ferrufiño, who appealed to a relative of his, an inquisitor, to get away with certain things, such as permission not to go to Juli and not to learn the language as the others do. ${ }^{20}$ It is difficult to say whether attempting to avoid mission work was common, and documents concerning Ferrufiño's career give no indication of whether he ever worked with Indians. ${ }^{21}$ In 1637, Juan Ternino wrote that he desired to join the Chilean missions and explained that 'those who want to undertake this activity are very few. ${ }^{22}$ In 1616 the procurator of the province in Rome, Juan Vázquez, tried to explain to the Roman authorities the negative view of mission work:

The mindset of these people, their ministry, is held in little esteem in the eyes of lay people, and, consequently, in the eyes of Ours, who apply themselves with more enthusiasm and facility to the brilliant dealings of Spaniards. That is the reason why it is so difficult for many of them to learn the language and to devote themselves to Indians. And even if the superiors order them to acquire some proficiency, sometimes they lack authority. If they are not vigilant in getting rid of the other hindrances and occupations. nobody will learn the language. This ministry also needs men realistic and humble enough to despise brilliant and reputable things and to devote themselves to despised and very lowly things. Fathers who do care for such things are men of great virtue and talent in the eyes of God. And they should be the same in the eyes of their superiors. They are the ones who work, because they know the language and are busy day and night. On the contrary. those who do not know it stay in their rooms or talk with their friends, or are out visiting all day long. ${ }^{23}$
Table 27.1

Jesuits and the Indian apostolate in the Peruvian province, 1576-1637

\begin{tabular}{lllllll}
\hline & 1576 & 1583 & 1595 & 1601 & 1613 & 1637 \\
\hline $\begin{array}{l}\text { Jesuits in the province (A) } \\
\text { Jesuits in the Indian }\end{array}$ & 73 & 136 & $\begin{array}{l}244 \\
(242)\end{array}$ & $\begin{array}{l}280 \\
(279)\end{array}$ & $\begin{array}{l}367 \\
(365)\end{array}$ & $\begin{array}{l}490 \\
(488)\end{array}$ \\
$\begin{array}{l}\text { apostolate (B) } \\
\begin{array}{l}\text { American-born Jesuits in } \\
\text { the province }\end{array}\end{array}$ & 23 & 13 & 38 & 49 & 70 & 152 \\
$\quad 10$ & 25 & 38 & 38 & 77 & 187 \\
$\begin{array}{l}\text { as \% of A } \\
\text { therican-born Jesuits in }\end{array}$ & 13.7 & 18.4 & 15.7 & 13.6 & 21.1 & 38.3 \\
$\quad$ as \% of B & 8 & 6 & 11 & 8 & 17 & 81 \\
\hline
\end{tabular}

Note: The numbers in parentheses refer to individuals about whom information is available in the documents. The place of birth of some individuals is unknown.

In the opinion of Alonso Ruiz, prejudices against the ministry to the Indians were very common among criollos. He wrote in 1585, 'Some of these criollos, as they call them here, even if they know the language better than those who come from Spain, use it with reluctance. And if they know one language they do not apply themselves well to another, even though it is easier for them because their ears are used to it. 24

However, criollos were not the only Jesuits who lacked a missionary vocation. In 1596, General Acquaviva wrote about the desire expressed by some Europeans to go back to Europe: 'I think the first reason for this desire is that work with the Indians is not sufficiently pleasant and satisfying. That is why they do not want to learn their language. And this kind of work does not make them happy. ${ }^{25}$ The opposition between criollos and Spaniards, frequently remarked upon in the historiography, does not seem to be borne out in this case. The two groups seem to have shared a reluctance for mission work. After a long period of discrimination, the position of criollos in the Peruvian province rose to one of great prominence, in the first third of the seventeenth century (table 27.1). They made up only 13.7 per cent of the province in 1576 and 21,1 per cent in 1613, but by 1637 the figure had risen to 38.3 per cent. The percentage of criollo participation in missionary activities was always greater than their proportion in the Society as a whole: in 1637, 63.3 per cent of the Jesuits who were or had been engaged in missionary activity were American-born. But figures have nothing to do with vocaltion: they show only that missionary activity had become almost

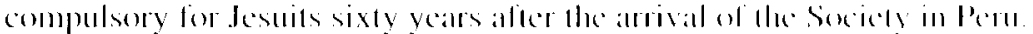


Seen in the context of increased local recruiting, this reluctance for mission work demonstrates that the Society's missionary project was not in keeping with colonial society's expectations of them. How to resolve this lack of vocation for mission ministry? The Society of Jesus tried to find a way of motivating students to study indigenous languages. In theory, Jesuits professed the fourth vow after they had finished their studies; the highest status in the hierarchy of the order was reserved for those who had studied philosophy for three years and theology for four years. To encourage vocations to the missions, the missionary provinces could apply more lax rules than those found in European colleges. In 1642 the provincial congregation of Peru reacted to a modification of the 1619 rules for instruction and asked for its suppression: 'It has been suggested that it was advisable to implore our father general to stop the privilege that has been granted to this province. The question is whether mediocre results are sufficient for one to be advanced from the cycle of arts to theology and from one year to the other. The aim of this is to promote to the fourth vow those who possess distinguished knowledge of the languages and who are eminent "workers" with Indians. Owing to this privilege, some of them have reached this level.

Fifteen fathers among twenty-four asked for the suppression of the privilege, because students had started to abuse it and begun to study much less than before. Their thinking was, '[If] mediocrity is enough, then I will learn the language and be able to make the profession, ${ }^{26}$ wrote the superiors in a letter to the general in 1642 . In their opinion the privilege was being abused:

Here the practice has been different. They are advanced showing mediocre results and without knowing the language, though keeping in mind that they have to learn it. They actually learn it later, and they are moved on by having preached a sermon committed to memory and perhaps well done, but without understanding what they are saying. It is clear that this is a fraudulent use of the aforementioned privilege and of the intention of our Father. Because the result is that they know neither the language nor theology at the level the Constitutions require. This is an abuse of the privilege, and that is why it ought to be suppressed. ${ }^{27}$

As far as I know, no work has been done on the differences between European and Latin American theological training and learning. The unique practices in Jesuit education in the Peruvian province, which I have pointed out here, would make for an interesting contrast with European practices. A similar situation existed in other parts of the Americas. For example, in late sixteenth-century Brazil, as Charlotte de Castelnau-L'Estoile discusses elsewhere in this volume, exceptional missionaries could replace Latin with the study of Tupí. Clearly. being a Jesuit did not have the same meaning everywhere in the world. In the case of Peru, students' attempts to thwart indigenous language instruction and avoid missionary assignments seemed to be clear and real. One of the more important reasons for these difficulties was that knowledge of indigenous languages was considered practical knowledge, a mere skill, and not genuine scholarly knowledge. If indigenous language-learning had an application in a geographical place (i.e., in the doctrinas), it did not necessarily play a consistent role in a Jesuit's education or career over time. Even if the Constitutions stressed the importance of learning local languages, the text did not mention when they had to be learned. It is logical that adaptations of the rule should be decided on a case-by-case basis by the father generals, but the generals were not always able to preserve the unity of Jesuit training throughout the world. Such limitations are logical for a living, expanding institution such as the Society of Jesus.

Many conclusions come to mind after this short presentation of the problem, and I would like briefly to touch upon some of them. First of all, the refusal to learn indigenous languages reveals that there were differing opinions among the Jesuits themselves as to the Society's missionary and apostolic vocation - both between the Jesuits in Europe and those in Latin America, and between missionaries and urban Jesuits within Peru itself. It shows that the question, What are we here for? would not receive a simple answer among the Jesuits of seventeenthcentury Peru. A Jesuit could ask, Are we here to teach, and to take care of Spaniards' souls, and spread among them the new ideas of the Council of Trent? Or he could ask, Are we here to take care of Indians' souls and convert those who are still unbelievers? All these activities continued, in spite of the contradictions and differing attitudes within the Society. The contradictions nevertheless reveal the difficult relationship that existed between missions and colonial society, and between the rules and precepts of Rome and local expectations of the Society of Jesus. Second, criollos and Spaniards seemed to share a negative view of missionary activity, a finding demonstrating that religious orders were often places of mutual acculturation and dialogue rather than cultural confrontation. One of the reasons might be that in the seventeenth century a large number of Europeans finished their studies in Lima and at a very young age, and therefore became as familiar with the criollo world as those who were born there. Finally, for us the idea of a unified Society of Jesus becomes difficult to preserve given the challenges of the new social and geographical realities faced by the Jesuits. Although the Society has often been portrayed as monolithic and rigidly homogeneous, further study of the differing educational methods and approaches to ministry throughout the Jesuits" worldwide enterprise will reveal a multificeled and often contradictory series of allitudes and a "coporate cullute" hat is lat froml unilomm. 


\section{NOTES}

I ARSI FG 1488/II/24 fol. 1: 'la teologia aca sera muda para predicar el evangelio y instituir en christianas costumbres a los yndios que es el principal asunto y fin de esta provincia.'

2 M Peru. 1:266: 'Los de acá saben todos la lengua y están hechos a la tierra; y mortificados bien y fundados en virtud, haran buenos conpañeros para los que de alla vinieren.' For Pizarro, see ibid., 1:258-9.

3 Blas Valera entered the Society upon its arrival in Peru in 1568. José de Acosta, who came only in 1574, was not the first provincial to open the doors of the Society to mestizos, as Bernard Lavallé has asserted, Recherches sur l'apparition de la conscience créole dans la vice-royauté du Pérou: L'antagonisme hispano-créole dans les ordres religieux (XVIe-XVIle) (Lille, 1982), p. 691.

4 Acts of the first congregation of Cuzco, 11 December 1576, M Peru. 2:68: 'Duas illas in hoc latissimo Regno generales linguas, quichuam et aymaram, cum fructificaturo in Domino necessariae omnino sint, Nostris studiose esse discendas. Quod sane fiet rudimenta quidem earum, et quae artis praeceptionibus constant, in collegiis discendo: mox vero, perfectam earum facultatem in ipsis indorum doctrinis, usu et exercitatione assidua, comparando. Id enim ex doctrinis indorum et facilius et commodius hauriri posse; neque ad ministerium sermonis ullam aliam esse magis compendiariam et aptiorem viam.'

5 Annual Letter, by José de Acosta, Lima, 11 April 1579. M Peru. 2:619: 'tienen gran exercicio de la lengua y cada día se juntan una o dos horas a conferir haciendo diversos exercicios de componer, traducir, etc., con esto tenemos ya experiencia que en quatro o cinco meses aprenden la lengua de los indios los Nuestros, de suerte que pueden bien confessar y cathequizar, y dentro de un año pueden predicar, $y$ assi ay allí cinco de los Nuestros que predican con gran facilidad y abundancia, y en esto se pone diligencia, porque se ve por experiencia que consiste en ello la conversión de los indios.'

6 Bonaventura Beati to Marcantonio Beati, Chuquiabo, I625, ARSI FG 1488/IV/3: 'Gia ho finito li studii, gia ho finito la terza probazione; gia ha un'anno che commincai a imparar la lingua Aymara, per auto si questa gentilità; sia lodato Iddio, ancorche non senza difficoltà per star nelli principii, confesso e predico nella lingua degl'Indii; e con la gracia del señore, il travaglio in dies, sara minore. e quando fosse maggiore; per tan buon Dio tutto si puo passare. Di sanità lodato Iddio mi trovo molto bene; e meglio che in Italia. Piaccia a Iddio la sappi impiegare bene nel suo santo servicio. Fra pochi giorni andró in missione, e sará la prima volta: Mi trovo hora nel Collegio di Chuquiabo; havendo stato 10 mesi nella Residenza de Giuli imparando la lingua, doppo havermi partito di Lima; dove tenni la 3a pro- bacione finiti li studii. Plura nellem pero non posso ser piú longo perche le continue confessioni non mi danno luogo.'

7 M Mex. 1:420.

8 Claudio Acquaviva to Baltasar Piñas, provincial of Péru, 21 November 1583, M Peru. 3:289: 'El orden que se ha dado a la Provincia de México acerca de aprender los Nuestros las lenguas de los gentiles entre los quales se hallan cuya copia se enbía con esta, desseo que Vuestra Reverencia haga tanbién guardar en esa provincia.'

9 Nicolas Mastrilo Durán to Acquaviva from Juli, where he is the superior, 15 March 1601, M Peru. 7:278: 'Los ministerios de los indios en las casas donde el Superior no sabe lengua, van con tanta floxedad que no parecen colegios de la Compañía.'

10 Ibid.

11 Ibid.: 'Añado que en esta Provincia no puede aver paz, si no ay igualdad en el trabajo, porque acontesce cada día y cada noche que los que saben la lengua trabajan notablemente y los que no la saben, como la ocupación de españoles es muy poca, están todo el día estudiando, o en buena conversación con seglares.'

12 Ibid.: 'La lengua es cosa muy fácil y que quienquiera que aprenderla quisiere, podrá salir con ella, y muy razonable, para predicar y confesar en 6 meses.'

13 His arguments are founded on the notion that the specialization of individuals should be according to their preferences and their talents - a notion that was applied, in his opinion, in the European provinces. Indeed, the Constitutions of the Society recommend that superiors select individuals for particular apostolates according to their personal qualities: 'Aussi, pour mener à bien ces missions, en y envoyant les uns et non pas les autres, en confiant à ceux-ci une charge et à ceux-là d'autres charges, est-il non seulement très important mais capital que le supérieur ait une pleine connaissance des inclinations et des motions de ceux dont il a la charge.' See Ignatius of Loyola, Constitutions, in Ecrits, ed. Pierre-Antoine Fabre (Paris, 1991), p. 414.

14 M Peru. 7:616: 'El ministerio de los indios a menester muy poco tiempo de studios, pues no hay de decilles conceptos ni predicalles escritura, sino aquel habla mejor y más a provecho que usa de cosas más llanas y manuales que se pueden decir de repente, y el ministerio de españoles no es así, sino que es necessario studiar para que el predicador sea oído y para que el confessor no yerre.

15 M Peru. 7:607: 'De continuar mucho las misiones, cobran los Nuestros un spíritu tan distraído, tam inquieto, tam enemigo de recogimiento y poco aplicado a oración y a disciplina religiosa, que quando buelven no ay quien los conozca ni quien los endereze.

16 M Perr. 7:617: "Por acudir a los indios se priva la Provincia de sujetos que la podrían alyudar en cosas de mayor importancia y los embían a missiones muy

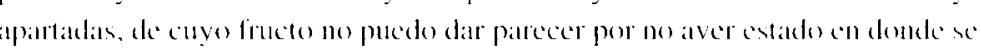


hazen y oír muy diversas opiniones entre los Nuestros: unos dizen son de mucho fructo y otros que de muy poco, y así tenemos pocas ayudas.'

17 M Peru. 7:607: 'Para este ministerio no son menester muchos sujetos, praecipue que el fructo que de él se coje no es tan grande como por allá suena, y esto no es cosa que tiene duda y la poca capacidad de esta gente lo da bien a entender.'

18 M Peru. 7:611: 'Están tam engañados con esta ordenación y tan ciegos, que se persuaden que no ay en qué entender ni cosa que agrade a Dios, sino confessar a quatro indieçuelos.'

19 M Peru. 7:618: 'Casi todos tienen un modo de privilegiados y que ellos solos son los de la Compañía y los demás no.'

207 August 1617, ARSI Peru 1A fol. 114: 'Piensase que el Padre Sebastian Ferrufino se vale de un pariente suyo inquisidor para salir con algunas cosas, como seria para no ir a Juli a deprender la lengua como otros, ordenarse antes de acabar sus studios, darsele el officio de ministro o Procurador de Provincia, a Vuestra Reverencia toca verificar la verdad que esto tenga y remediarlo como conviene.'

21 Sebastián Ferrufiño came from Seville and entered the Society in 1603, according to the catalogue of 1607 . At that time he was 25 years old and lived in Lima at the San Martín college. He had just begun his studies (ARSI Peru 4 I fols 103v-124). In 1613 he was a priest but had not yet made his profession. He lived in the college of Lima, where he had been a minister and a procurator. There is no mention of any contact with indigenous people.

22 Lima, 1 April 1637, ARSI FG 1488/IV/4: Juan Ternino asks the general for permission to go to the Chilean missions with books 'acomodados para un misionero a que yo tengo interior y exterior propension, e inclinacion lo uno por aver tan pocos que quieran ocuparse en este ministerios, lo otro por lograr y no perder lo que Nro Señor me a dado en que sepa las dos lenguas del Piru, aymara y quichua ... Son muy pocos los que quieren emplearse en esto.'

23 ARSI Congr. 55 fol. $128 \mathrm{r}-\mathrm{v}$ : 'La cabeça desta gente haze de poca estima su ministerio delante de los ojos de los seglares y por consiguiente de los nuestros, que con mas gusto y facilidad se aplican al trato lucido de los españoles. De aqui se saca la raiz de la dificultad que muchos tienen en aprender la lengua, y en aplicarse a los yndios, y aunque los superiores procuran aplicarlos, a vezes no son poderosos, y si no son vigilantes en quitar los estorvos y ocupaciones diferentes, no abra quien la aprenda. Sacase tambien que este ministerio a menester hombres humildes y desengañados, para dexar lo lucido y honrado, y para aplicarse a lo menospreciado y abatido, con que se dexa entender que los padres que se dedican a ello, son hombres de mucha virtud, y merito para con Dios, y lo deven ser para con los superiores. Son los que trabajan, porque con saber lengua, se ocupan de dia y de noche sin descanso y los que no saben lengua se estan en su celda, o estan parlando con sus amigos, o visitando todo el dia.
24 Alonso Ruiz to Acquaviva, Cuzco, 26 December 1585, M Peru. 3:723: 'Una cosa deseo y la he dicho al Padre Provincial, que también la desea, que se diesse orden para que los que entran acá se aplicassen a la ayuda de los naturales, porque muchos dellos, después de averles dado estudios la Compañía, no ay quien les applique a indios, sino a españoles, y plega a Dios que no les mueva la honra o el menos trabajar, y aunque con lo que Vuestra Paternidad de parte de Su Sanctidad y suya ha escrito y encomendado, se comiençan a alentar más, pero represéntaseme que ayudaría mucho si Vuestra Paternidad ordenasse que ni se admittan a Ordenes ni se incorporen del todo en la Compañía por professos y coadjutores formados los que no se aplicaren de veras a este ministerio, y que sea este un modo de probación aun en el tercero año, porque algunos destos criollos, que assi se llaman por acá. aunque sepan mejor la lengua que los que vienen de España, violentamente se applican a esto, y si saben una lengua, mal se applican a otra, siéndoles a ellos más fácil por tener hecho el oído.'

25 Instructions to the Visitor of the Province of Peru, October, 1596, M Peru. 6:222: 'La razón particular deste deseo creo que es que la ocupación con los indios no es tan gustosa ni aplausible, y por esto no se aficionan a aprender su lengua, y ansí no tienen empleo proporcionado para vivir contentos.'

26 Provincial Congregation, 1642, ARSI Congr. 71 fol. 108: 'mediocridad me vasta, y despues aprendere la lengua, y con esto haré la profession.'

27 Ibid.: 'Pero aca se ha practicado differentemente, por que sin saberla van pasando con la mediocridad, intuitu de que aprenderan despues la lengua, y despues la aprenden muy de cumplimiento, $y$ an pasado con que predique un sermon tomado de memoria, y quiça trabajado destro, y sin entender lo que dize. Y esto claro es, que es en fraude del dicho privilegio, y de la mentalidad de Nuestro Padre pues se queda sin saber la lengua, y sin saber theologia con las calidades, que la constitucion pide, y esto es abuso del privilegio y gracia y como tal sc debe quitar.' 